\title{
Relations between the European Union and Russia in the light of the notion of Empire
}

\author{
Carlos R. FERNÁNDEZ LIESA*
}

\begin{abstract}
This article has the object to analyse the relationship between the European Union and Russia in the light of the Empire notion. Research focuses not what is happening today but in their interpretation, taking into account Empire notion, in the European Union and Russia. The core idea is that the Empire notion continuous to have relevance in the State system; the evidence is the international practice and the history of International relations. The notion of Empire has not been taking into account sufficiently in the analysis of International law. Furthermore we have analysed the situation in the globalisation and the de-territorialisation of power. The conflicts and the practice of International law have been analysed.
\end{abstract}

Keywords: Empire - European Union-Russia relationships. International law

\section{(A) EU-RUSSIA RELATIONS}

The purpose of this article is to analyse relations between Russia and the European Union from the perspective of their respective identities, as players on the stage of international relations, and of the idea of Empire, nowadays neglected and ignored by international legal doctrine.

Excellent analyses, such as that by Antonio Blanc Altemir ${ }^{1}$, have already been published on commercial, energy and other relations between the two regions, as well as on the framework of the various conventions, from the 1994 agreement to the TACIS and ENPI programmes, the four common spaces and the more recent partnership for modernisation. These relations have traditionally been marked by conflict and cooperation and can be divided into three distinct stages: one under Yeltsin (19912000) and two under Putin, before and after the conflict over Georgia (and subsequently over Ukraine), all of them conditioned by Issues such as oil, Chechnya, political and economic instability, Georgia, Ukraine and Crimea.

Russia has historically claimed specific differential treatment from the EU, in recognition of its role as a global player. The combination of disputes with some Member States on the one hand, and recent events on the other, however, has led to a hardening of relations that steadily worsened over the period between the 2008 Russo-Georgian War and the annexing of Crimea in 2014, as Blanc points out in his analysis. At the time of writing the situation has not improved, in spite of the mutual interdependence in commerce and energy between the two regions. Furthermore, on 2I November 2013 the Ukraine government decided to suspend negotiations over the Association Agreement with

\footnotetext{
Professor of Public International law. Universidad Carlos III de Madrid.

A. Blanc, La Unión Europea y los BRICS (Brasil, Russia, India, China y Sudafrica), (Ed Thomson Reuters Aranzadi, Ist edition 20I5), $2 \mathrm{I2}$.
} 
the EU, opting instead to form part of the Eurasian Economic Union, promoted by Russia. The way in which events have subsequently evolved has led to the current critical situation, one on which both sides need to reflect, but from a much broader perspective. The focus of this article is therefore not so much on recent events as on analysing EU-Russia relations in the light of the idea of Empire.

\section{(B) RUSSIA AND THE EUROPEAN UNION: TWO DIFFERENT VIEWS OF EMPIRE}

When it comes to analysing the relations between the EU and Russia one has to consider the matter of a nation's soul, its very nature, if such an expression can be used, in the broadest possible sense. Russia has from the outset been characterised by its imperial nature, first under the Tsars, then under the Soviet system ${ }^{2}$ and subsequently down to the present day. In contrast, the EU is a region of lost empires in search of an identity.

Russia started on its process of geographical expansion under Ivan the Terrible, growing in size from approximately 24,000 square kilometres (9,265 square miles) in 1462 to 13.5 million square kilometres ( 5.2 million square mile) in 1914 as a consequence of strategic and economic causes: an imperial system based on the ideology of Russian exceptionalism (and the doctrine of the Third Rome). The Tsarist Empire toppled as a result of World War One and the Soviet Revolution, being replaced by the Soviet Empire, that of the USSR, which extended its control (by military means when necessary) over a large number of territories.

Furthermore, after World War Two the USSR expanded the area under its control to include the countries falling within its sphere of influence, its external Empire, covering a large part of Central and Eastern Europe, and created a number of international organisations as one of the various ways in which it exercised its influence. With the collapse of the Soviet Empire the internal empire disintegrated, its fifteen republics becoming independent states. Nowadays, the Putin doctrine has led Russia to attempt to maintain an imperial stance in a multipolar world. Russia sees the EU and the US as obstacles restricting its capacity to influence; it is rebuilding its international position with the help of powerful resources such as its territory, its nature as a Eurasian country, its nuclear forces and military might, its natural resources, its historical role and sphere of influence, the reorganisation of alliances and the existence of minority Russian populations in third countries, amongst others 3 .

In contrast, the European Union came into existence at a time when European empires were collapsing; in this sense a parallel can be drawn with the Eurasian Economic Union promoted by Russia. The Spanish and Portuguese Empires, with their seaborne expansion in Asia and the Americas, followed by the French, British and Dutch Empires and later, in the nineteenth century, by the Belgian, German and Italian Empires in Africa, meant that European countries acquired an imperial identity as individual states, not as the United States of Europe and much less as the European Union. Europe's rise and fall occurred between the beginning of the modern era and World

\footnotetext{
G. Graeme, "Russia: los dos Imperios", in G. Graeme (Ed), La era de los Imperios (The Age of Empires), (Blume, 2007) at $176-196$

3 N. Melvin, "Russia: Europe's revisionist power", in Challenges for European foreign policy in 2015. How others deal with disorder. (Fride, Bruxelles, 20I5) 3I-39, at. 35
} 
War Two: empires such as that of Spain helped to lay the foundations of international society and international law ${ }^{4}$; classical international law was the product of imperialism and a means, as Anghie points out ${ }^{5}$, by which European nations promoted their own interests.

The nineteenth century witnessed a huge expansion of European power during which the world's land surface controlled by its countries increased from $35 \%$ to $85 \%$ between I800 and 19I4, aided by capitalism and the rapid growth of technology ${ }^{6}$. Hobsbawm, in his excellent analysis of the age of empire (1875-1914), analyses how most of the world outside Europe and the American continent, which by then formed part of the international system of civilised (and, according to Truyol, Christian) states, were either formally governed by, or came under the informal political sway of, the United Kingdom, France, Germany, Italy, the Netherlands, Belgium, the United States and Japan; Western powers established areas of influence or direct rule in the traditional large Asian empires ${ }^{8}$, whilst Africa belonged to European empires alone. Europe, as a political concept, thus came into existence at a time when the European empires that once ruled the world were crumbling, and has still not succeeded in taking their place in that dimension. Europe's imperial strength meant that the universalization of international society took place in its own image and likeness, Euro centrism being a significant factor in the international order'.

Nowadays, however, we are faced with a post-imperial Europe that is still seeking its place in the world $^{\text {io }}$. As Crespo Maclennan points out, the main conclusion that Europeans have come to, after two World Wars, is that they cannot afford to be divided and thus the unification of Europe has become an ambition, not merely a pipe dream. True unification would bring with it formidable economic and political power, sufficient to enable it to recover its world hegemony. The project, however, is still to solidify, probably because it needs more time to ripen, or so we hope.

The European Union's difficult position in the face of globalisation and its enlargement, the failure to approve a European Constitution in 2005, the economic crisis that started in 2008 and the subsequent social crisis have led to an identity crisis for the European model. The last 25 years have seen reforms such as those of Maastricht, Amsterdam and Nice, culminating with that of Lisbon. But this is not enough: the EU needs to renew its project of integration along much clearer lines in order to face the challenges of globalisation and enhance its current degree of integration, for which larger doses of collective ambition are needed. It is not just a matter of defining, from a legal perspective, whether the EU is a state, an international organisation, a federation, a confederation or a super-state;

\footnotetext{
4 On the Spanish Empire: s H. Thomas, H. El Imperio español. De Colón a Magallanes/Rivers of Gold. (Editorial Planeta, Barcelona, 2003) 894. H. Kamen, Imperio La forja de España como potencial mundial/Spain's Road to Empire. The making of a world power. I492-1763. (Editorial Santillana, 2003), 939. The perspective of international law has been studied by, amongst others: H. Koskenniemmi, "Imperio y Derecho internacional. La verdadera contribución española", in Y. Gamarra (Ed), Historia del pensamiento iusinternacionalista español del siglo XX (Editorial Thomson Reuters, Madrid, 20I2) at. 379.

A. Anghie, Imperialism, sovereignty and the making of international law (Cambridge University Press, 2004) 352 , at 5.

D.R. Headrick, El poder y el Imperio (Editorial Crítica, Barcelona, 20I0, 20II) at Io.

A. Truyol La sociedad internacional (Editorial Alianza, Madrid I99i).

E. Hobsbawm, La era del imperio (Editorial Crítica, Barcelona, 20I2) 728.

C. Fernández Liesa, Cultura y Derecho internacional (Editorial Universidad Alcalá de Henares, Madrid, 2012), 225

C. Maclennan, Imperios. Auge y declive de Europa en el mundo, I492-20I2. (Editorial Galaxia Gutenberg, Madrid, 20I2) $5 \mathrm{I} 8 \mathrm{pp}$, at 425 .
} 
it is a question of it having a global ambition to match its history and its economic and cultural power.

(C) DISCUSSIONS ON EMPIRE IN THE POLITICAL SYSTEM AND IN INTERNATIONAL LAW.

The creation of the system of European states, in the modern era, saw the beginning of the dilution of the idea of empire in studies on international law, an error that distorts the perspective. Legal formalism and the lack of interdisciplinary analyses on the part of many international law scholars have led to state-centric views of society and international law that have no place in today's globalised world.

\section{(I) On the continuity of Empires in the system of European states and their universalization}

There is nothing to allow us to think that the birth of the system of European states caused the disappearance of empire. Empires are characterised by their expansive nature and develop through expansion, through the conquest or annexation of new territories. Although it is true that the conquering of territories is prohibited under international law, it is a very recent phenomenon in the international order, only having been introduced in the UN Charter. This prohibition therefore, cannot be the reason for the end of imperial expansion and conquest: empires came to an end, or their expansionism was greatly reduced, when the whole world fell under their domination, two world wars had taken place and the Cold War had arrived.

As Carl Schmitt has explained, land-appropriation was a constitutive act of law, that of 'radical title'. In the modern era, the division and distribution of space commences with the conquest of the New World, which rather than a foe was seen as "free space, as an area open to European occupation and expansion". European public law, he states, ended when the New World began, as did a "struggle for land-appropriation which knew no bounds". But with the dissolution of the jus publicum europaeum, which Schmitt places during the period between 1890 and 1918, its place was occupied by an empty normativism of allegedly recognised rules that obscured consciousness of the fact that a concrete order of previously recognised powers had been destroyed and that a new one had not yet been found. The period between 1890 and 1939 saw the end of that spatial order of the earth that had supported traditional, specifically European international law and the bracketing of war it had achieved.

Leaving Schmitt's Nazism (criticised in a previous article ${ }^{\mathrm{II}}$ ) to one side, there can be no doubt that the universalization of international society during the twentieth century brought about a transformation and change of meaning of empire and imperialism, in the classical sense, once the failure of Hitler's plans for Lebensraum had come to nothing. The earth's land mass is finite, and its redistribution is no longer possible under the rule of law, but that is not to say that empires or

\footnotetext{
II C. Fernández Liesa, A. Kramarz, "Estudio sobre el libro de C. Zarka Un detalle nazi en el pensamiento de C. Schmitt", 2I Derechos y libertades (2009), 285-292, at 290.
} 
imperialism have ceased to exist, nor that geopolitics has ceased to have a function.

Burbank and Cooper ${ }^{12}$ have analysed the world of nation-states we now know, which is little more than sixty years old, in comparison with the thousands of years of empire, whose politics, practices and cultures continue to shape our world. For their part, Buzan and Little highlight the exaggerated role given to state centrism in the analysis of the structure of the international system ${ }^{\text {13. }}$.

Luard, after analysing the different types of international society down the ages ${ }^{14}$, demonstrates that forms of hegemony have prevailed between the members of all international societies. Watson, after studying the evolution of international society ${ }^{15}$, highlights the role of hegemony during the various different historical periods, including ancient systems, medieval European society, the Renaissance, the Westphalian system, European expansion, the collective hegemony of the concert of Europe and today's global international society, from the collapse of European domination to the East-West conflict, decolonisation and contemporary international society.

It is thus appropriate to consider that the study of empires over the course of history points to the significant role they have played, and continue to play, in the international system and international law, to the extent that it is in our view legitimate to affirm the continuity of empires within the system of states. They have proved to be contemporaries of the dinosaurs that survived a total transformation of the system, hidden under the formalism of law and demonstrating their vitality on many an occasion.

If historians have debated the continuity of empires ${ }^{16}$, then no less can be expected in the field of international law. Authors such as Truyol ${ }^{17}$ have in the past produced studies highlighting the fact that the idea of empire was a factor common to all systems of international law. Thus, ancient Eastern civilisations had their Concert of Empires, China considered itself to be the Middle Empire and the Great Mogul Empire enjoyed an importance that is nowadays forgotten, whilst the Roman Empire (arbiter mundi) came back to life in Charlemagne's court, becoming the Imperium christianum (sacrum Imperium).

Although all this changed with the advent of the Westphalia system, it should not be forgotten that the new order of the modern era was in fact compatible with all the European empires that would thenceforth be built, with the existing ancient empires in other civilisations and with imperialism and other forms of hegemony and domination that are compatible with international law and the idea of sovereignty and equality between states, except for those notions that are incompatible with reality. For this very reason authors such as Anghie are of the opinion that we live in an era of ongoing

\footnotetext{
I2 J. Burbank, F. Cooper, Imperios. Una nueva visión de la bistoria universal, (Critica, Barcelona, $201 \mathrm{I}) 699$.

${ }_{3}$ B. Buzan, R. Little, International system in world bistory. Remaking the study of international relations (Ed. Oxford University Press, 2010) 447

${ }_{14}$ The societies he analyses are the ancient Chinese system (77I-22I BC), the Greek city-states (510-338 BC), the age of dynasties (1330-1559), the age of religions (1559-1648), the age of sovereignty (1648-1789), the age of nationalism (1789-1914) and the age of ideology (1914-19). E. Luard, Types of international society (London, 1976), at 38r.

is A. Watson, The evolution of International society. A comparative bistorical analysis (Ed. Routledge 1992, 2009) at 334.

16 E. Hobswabw, La era del imperio, supra n. 8, p. 678.

17 A. Truyol Serra, Historia del Derecho internacional publico (Spanish language version by Paloma García Picazo, Ed. Tecnos, Madrid, 1998), in toto.
} 
empire, under a variety of new forms ${ }^{18}$.

(2) On the future of Empire in an age of unilateralism, bipolarism and multilateralism

In more recent times the transformation of the state, the end of the Cold War and the constraints of globalisation have led to a transformation in the theory of empire.

On the one hand, North American unilateralism ${ }^{19}$, after the end of the East-West conflict, alerted the doctrine and nations to the dangers it supposed for the healthy evolution of international law ${ }^{20}$. The state-centric vision of the US government, especially under George W. Bush, reflected the behaviour of an empire, the 2003 Iraq war being the paradigm of its imperial policy. North American unilateralism was reflected from the mid-rg9os onwards in measures such as the change in the strategic concept of the Atlantic Alliance, announced on 24 April 1999, which envisaged actions outside its boundaries (backed by a large number of EU Member States). There has been a growing number of unjustified hegemonic behaviours, in defiance of the international order, coinciding with a lack of support for initiatives to protect the environment or combat the impunity of major crimes against humanity. Here, however, is not the place to enumerate the failings of the greatest power of the present moment.

On the other hand, neither has the transformation of the balances with Russia appeared to announce a multipolar world, as was seen in the case of the 1998-99 war over Kosovo. The attacks against the Twin Towers on II September 200I brought the USA's national security strategies to the summit of unilateralism, ignoring international law and rejecting multilateralism, a prelude to the Iraq War and the doctrine of the pre-emptive use of military force.

National conceptions of international law ${ }^{2 \mathrm{I}}$, which shape to excess the interpretation of the international order in the light of national interests, have always existed. In the event of a conflict between national interest and international law, many states and their jurists put forward a forced interpretation of principles and rules; this has led to a structuring of these national conceptions of international law, which aim to legitimate the unsustainable in order to defend vital or special

I8 A. Anghie, Imperialism, sovereignty and the making of International law, supra n. 5 at 355 .

19 A. Remiro Brotons, "Universalismo, multilateralismo, regionalismo y unilateralismo en el nuevo orden internacional", Revista española de derecho internacional (199I), at I5 ; A. Remiro Brotons, "Desvertebración del Derecho internacional en la sociedad globalizada", 5 Cursos euromediterráneos Bancaja de Derecho internacional, (200I), at 2I4.; various authors, "Unilateralism in International law: Its Role and limits", II, I,2 European Journal of International law, (2000); J.I. Sánchez Rodríguez, "El desafío del poder imperial al ordenamiento internacional general", in Derecho internacional y crisis internacionales, Madrid, Iustel, 2005, at 223-250; P. M. Dupuy, "The place and role of unilateralism in contemporary international law”, European Journal of international law, 2000, at. 19-29; F. Fukuyama, America en la encrucijada. Democracia, poder $y$ berencia neoconservadora (Barcelona ed. B, 2007); various authors, El nuevo orden americano. ¿La muerte del derecho? (Almuzara, Córdoba, 2005); T. Todorov, El nuevo desorden mundial (Ed. Atalaya, Barcelona, 2003); M. Byers, G. Nolte (Eds), United States hegemony and the foundations of International law. (Ed. Cambridge, 200I) 531; P. Sands, Lawless world. America and the making and breaking of global rules (Ed. Viking, 2005) 326; Various Authors, "Hegemonic law revisited", 97, 4 American Journal of International law (2003).

20 C. Fernández Liesa, "La relación entre Poder y Derecho en el Derecho internacional”, Estudios en bomenaje al profesor Gregorio Peces Barba (Dykinson, vol. II, Madrid, 2008), i189, at 449-497.

C. Rousseau, "Les conceptions nationales du droit des gens", Mélanges offerts à Paul Reuter. Le Droit international: unité et diversité. (Ed. Pedone, París, I98I) 44I-446. 
interests.

Thus, for example, the retrocession of Crimea to Russia can be seen as perfectly sustainable. It had been donated at a time when it was thought that the USSR would last a thousand years; thus, the separation of Ukraine as a result of the disintegration of the USSR would have been the time to negotiate the retrocession. But as this happened at a time when Yeltsin betrayed Gorbachev, it was impossible for this to be done at the right time or in accordance with international law. What has now been done cannot be right: national conceptions of international law seek to shape the latter to their own ends, no easy matter because to do so they would have to control and/or lead the international community as a whole, an imperial power that not even the United States has managed to achieve in the contemporary era.

We have to return to the time of the East-West conflict in or to understand how sovereignty, in both the USSR and the USA, was envisaged from the perspective of their hegemonic power. Thus, the Soviet doctrine of international law up to the Tunkin era and the right to co-existence projected the basic ideas of Marxism-Leninism on relations between states and the role of international organisations on international relations, reflected in its position on the nature of the Charter and its restrictive interpretation of international treaties ${ }^{22}$. The same occurred in the case of the United States' conception of America ${ }^{23}$; we should remember the famous moment of the Cuba missile crisis in 1962 that led Dean Acheson, the US Secretary of State, to say, not at a political rally, but in a book that "law simply does not deal with such questions of ultimate power-power that comes close to the sources of sovereignty." No law, he was later to declare, can destroy the state creating the law. The survival of states was not a matter of law ${ }^{24}$.

Although the above by no means calls international law into question, it does reveal that the relationship model between law and power is, in an international society without a global state, a dialectical relation of complementarity, from which the evolutionary characteristics of the international order proceed. This notwithstanding, international law does help to prevent inequalities in power, territory, population or wealth becoming a literal translation of relationships of power in the norms, even though they reflect the consent of those who have the power to create, interpret and transform them. From a historical perspective, we can talk about an objectification of order, a progressive distancing from state-specific interests in favour of more general ones.

In the twenty-first century, it would appear that we are heading towards a multipolar international system, overcoming to a certain extent the preceding situation of unilateralism and bipolarism. However, this multilateralism does not imply that imperial tendencies have also been overcome, since the different points constituting such a multipolar world can be identified with empires, obliging us to keep the idea of empire under consideration.

${ }^{22}$ McWhinney, "Contemporary soviet general theory of international law: reflections on the Tunkin era", XXV, Canadian Yearbook of International law, (1987), I87-217; C. Zorgbibe, "La doctrine soviétique de la souverainété limitée”, 4 Révue Générale de Droit international public (1970), at 872.

23 R. Charvin, "La doctrine américaine de la souverainté limité", Révue belge de Droit international, I (1987) 527, at 6

24 E McWhinney, Conflit idéologique et ordre public mundial (Pedone, Paris, 1970) 29 


\section{(3) On the idea of Empire in an era of globalisation and de-territorialisation}

The interstate nature of the international order has been called into question by the new role being played by international civil society or as a result of the weakening of the state, amongst other factors.. Authors such as Hardt and Negri ${ }^{25}$ analyse the idea of empire not so much from the perspective of borders or territorial expansion as from new paradigms. Globalisation, in their view, has created a new situation, a significant historical shift, in which law, authority, territory and the idea of sovereignty and power are mutable. They consider that states can longer constitute the nucleus of an imperialist project, and henceforth no single nation will be a world leader as modern European nations once were. The empire, they affirm, will be the political subject that regulates global exchanges, the sovereign power that rules the world in an irreversible and implacable process of globalisation. They use the word 'empire' to refer to this new global form of sovereignty, in a way that strikes us as somewhat indeterminate and ambiguous, although it does highlight the importance of the de-territorialisation of power.

The relation between law and space is a highly significant one and forms the foundation of international law, which is based on the European concept of legal space linked to the notion of national borders that circumscribe a state's sovereignty. But, as Losano points out ${ }^{26}$, the end of the Cold War, globalisation and the de-territorialisation of the economy means that space in law is no longer what it was a century ago; globalisation has nullified national borders and new notions have appeared (global law without a state, law without borders or the global legal space, amongst others) that indicate that we have moved on from the concept of state space (the territory occupied by a state) both as a result of the existence of rules of non-state origin and of the geopolitical demands of an energy-related or military nature; in this author's opinion the solution is for the pyramidal and hierarchical structure of law to exercise its regulatory function and, even though the phenomenon of globalisation might be irreversible, the state or supranational organisations should have instruments at their command to control it, particularly in the case of multinational companies. This, he says, is possible because history has shown it to be. After World War Two the multinational companies that had acted in oligopolistic or monopolistic contexts shrank in size. Empires, like energy, transform themselves but it is hard to imagine their debellatio.

(D) THE EUROPEAN UNION AND RUSSIA AS DISSIMILAR GEOPOLITICAL PLAYERS: EMPIRE VS CIVILIAN POWER.

In this section, we will look at relations between the EU and Russia in the light of some of the factors that have led to a number of recent crises, and the resources available in each case for tackling them. The results of this analysis reveal that in all probability the European dream of being a civilian power cannot always be maintained, and that in any event it is no easy matter for such a dream to challenge

25 M. Hardt, A., Negri, Imperio, (Ed. Paidós, 2000, 2005) at. I3.

26 See M Losano, Discurso de investidura como Doctor honoris causa por la Universidad Carlos III de Madrid, 28 January 2010. 
or oppose an empire.

\section{(I) Russia as Empire and the EU as civilian power}

The EU aims to be a civilian power in a globalised world that has undergone a transition from geopolitics to geo-economics. As far as globalisation is concerned, military power is less relevant than other resources to which the EU is better suited, a fact that cannot be denied. Nevertheless, some authors adopt a different view and prefer to see the issue in terms of a blatant decline of European power and influence ${ }^{27}$. I will not offer any opinion on this subject in general terms, since I believe that the EU is necessary; however, it is a process that will take time to solidify and affirm its status on the international stage as well as domestically.

There can be no denying that the EU possesses a number of significant resources to enable it to become a major player in a globalised world. In this regard, it is a leader in the fields of commerce and finance; a supportive player and a defender of values that has managed to maintain a positive image in spite of recent doubts arising from the refugee $\mathrm{crisis}^{28}$; a point of reference for democracy, human rights, culture and values; and it agglutinates a group of the world's leading economies that whilst retaining their individual identities as countries have succeeded in achieving a high level of economic integration.

On the other hand, the EU also displays a number of weaknesses that debilitate it in the sphere of international relations and have prevented it from becoming a decisive player on the international stage. One of these is the difficulties it experiences in reaching consensus, when means that European foreign policy is more reactive than pro-active, constantly lagging behind events. What is more, it is hard to overcome the heterogeneity of its Member States' interests, which has increased even further as a result of the EU's enlargement, through its decision-making consensus mechanism. Another factor that does not help in this respect is the lack of definition of the European Union's borders.

The EU thus faces a problem of definition of its own interests on the world stage, a problem that does not affect Russia, whose leaders display an extremely clear and firm political will. To put it another way, the EU's foreign policy model is complex, ineffective and not yet fully developed, reducing its effectiveness in the process of globalisation. One only has to contemplate the situation in its immediate environment in the Middle East, North and Central Africa or Eastern Europe to reach the conclusion that the EU has been unable to create safe, prosperous and democratic spaces, in spite of its policies. The blame for this state of affairs may not lie directly at the EU's door, but neither has it been able to prevent it from happening.

Russia is an empire that has suffered a relative erosion or weakening of its power, but has no desire to be anything else. In Kissinger's opinion ${ }^{29}$, after the fall of the Roman Empire pluralism became the defining model in the Middle Age; over time this pluralism adopted the characteristics of a model of world order, and when the Peace of Westphalia ushered in the concept of equality between states the

27 See, for example, R. Youngs, Europe's decline and fall. The struggle against global irrelevance (Profile books, 2010) 228

28 See, for example, a highly critical analysis from this standpoint: J. Lucas, Mediterráneo: el naufragio de Europa. (Tirant Humanidades, 2015) I55

29 H. Kissinger, Orden mundial, (Debate, 2016) at 23 
model's foundations became the balance of power in Europe, a status that came to an end before the international system, present or past. In other words, the international system was the result of the expansion of a pluralist European system, the result of Europe's history.

Russia, Kissinger tells us $^{30}$, had learnt its sense of geopolitics from the hard school of the steppe. If Europeans associate security with balance of power and constraints on the exercise of power, in Russian history such constraints have resulted in disaster; the expansionist Russian vision gave rise to a different concept of political legitimacy, far removed from that of EU Member States.

When it comes to analysing its future as a power, we should remember that Russia is a Eurasian power, whilst the EU is only a European one. In this regard Russia has never been an exclusively European country, and its European identity, as Remiro has pointed out, is a complex and controversial issue ${ }^{31}$. Despite its Westernisation at various different times and the fact that it was one of the driving forces behind the Congress of Vienna, it has never become (or been allowed to become) fully integrated into the Western European system. Proof of this can be seen in the Crimean War, the immediate cause of which was the protectorate of the Holy Places in Jerusalem. Subsequently, one of the consequences of both World War One and World War Two was to distance Russia from the centre of Europe, this being accompanied by the creation and rise of the Soviet system.

29 May 2014 saw the signing of the Treaty of the Eurasian Economic Union, which came into force on I January 2015. Russia is also a member of BRICS and the Shanghai Cooperation Organisation, amongst other international forums and bodies, all of which constitute some of the pieces that Russia is using to attempt to restore its international position and set itself up as a world power. If we reflect on this issue we have to agree with John Darwin ${ }^{32}$ and other authors that the Western narrative of world history is increasingly being called into question, with Europe (and the West in general) being seen in a wider context, in oblique projection. This standpoint has led to a rewriting of the history of European expansion, challenging the Eurocentric view of the history of the modern world. It is now being put forward that Europeans were the last to become members of a vast seaborne network of trade pioneered by Asia, linking China, Japan, Korea, South-east Asia, India, the Persian Gulf, the Red Sea and East Africa; the global economy already existed, and there was no need to await the Promethean touch of merchants from Europe ${ }^{33}$. Looked at from this angle, the position of Europe in world history and that of empires changes considerably, and authors such as Mishra have even announced the rebellion of Asia against the West ${ }^{34}$. It is not a question of announcing a wholesale transformation of our world view, but as Western Europeans we should make an effort to see the world not just from our European windows, but from those of the entire world, thereby diminishing our stature and importance in our own eyes. Such a perspective, in the context of a multilateral world, would make it possible to alter our focus and even adopt new approaches.

\footnotetext{
30 Orden mundial, ibid. p. 6r.

${ }^{31} \quad$ For an analysis of Russia's European identity from a variety of standpoints see A. Remiro Brotons and others, Los límites de Europa, Academia Europea de ciencias y artes, España, 2008, 459, at 253.

32 J. Darwin, El sueño del imperio. Auge y caída de las potencias globales. I400-2000 (Taurus, 2012) 610

33 J. Darwin, El sueño de imperio. Auge y caída de las potencias globales. I400-2000, (Taurus, 20I2) at 33

34 See P. Mishra, De las ruinas de los Imperios. La rebelión contra occidente y la metamorfosis de Asia (Galaxia Gutemberg, 2015) 519.
} 
(2) Some of the conflicts between Russia and the EU, seen in the light of their nature

If we look at some of the issues on which the EU and Russia have come into conflict from a geopolitical standpoint, it becomes clear that the theory of civilian power is not wholly sustainable, as shown by the former's dependence on Russia for energy. International conflicts generated by a shortage of resources can occur on a grand scale ${ }^{35}$. The European Union's energy dependency affects European security and is a source of weakness in its relations with Russia. Energy diplomacy is a core element for the US, Russia, China and, indeed, the majority of states in general. To date the EU has failed to play a relevant role in this regard in order to ensure its energy supply, despite its significant dependence on external sources and the fact that it is the leading importer and second largest consumer in the energy market. Russia has no direct involvement in Energy Charter activities, believing that it only benefits energy purchasers, and nor does the United States, which prefers to see no change in the EU's current situation. Another element of uncertainty comes from the transport of energy by means of gas pipelines: the efforts of Russian, North American and European diplomacy have been to little avail in clarifying the situation, which affects Europe's energy supply. Countries such as Germany, Italy or France, along with the majority of other European nations, have signed long-term energy supply agreements with Russia (or with Gazprom), leaving the EU and collective interests to one side in a further demonstration of the former's weak position as an international player.

Furthermore, the EU also suffers from a noteworthy military dependence, especially since the United States and the EU (or some of its Member States, at least) diverge in their appreciations of international law and the role it should play. Kagan ${ }^{36}$, for example, considers that the difference in perspective between the US and the EU in questions of power is a consequence of the weakness of the latter, which has created a transatlantic divide (aided by the lack of a common strategic culture) that may be impossible to reverse. For his part, Habermas ${ }^{37}$ considers that "the dispute (between the US and the EU) revolves around whether the law is the appropriate means through which to achieve this objective [the defence of international security and stability, global attainment of the intercultural core of democracy and human rights) or whether the best means, on the other hand, is the unilateral policy of a world power that aims to impose order". At all events there is a certain difference of conception between the EU and the US that has led to certain problems with Russia for which Europeans must obviously shoulder much of the responsibility. These include:

(i) The Anti-Missile Shield. In 2008 the United States signed agreements on the anti-missile shield with Poland and the Czech Republic, which were part of the system designed by the US to "face

35 Thus, taking water as an example, we can cite the real or potential conflicts generated by the shortage of this resource in Sudan, the Nile basin, Lake Chad, the Middle East and the Dead Sea, amongst others. See J. Solana, El acceso al agua. Un nuevo desafío (Ed. Exposición Internacional de Zaragoza. Expoagua, Tribuna abierta, 2008); M. Klare, Guerras por los recursos. El futuro escenario del conflicto global (Editorial Urano tendencias, 2003). E. Menéndez, A. Feijoo Lázaro, Energía y conflictos internacionales (Editorial Netbillo, 2005).

36 R. Kagan, Poder y debilidad. Europa y Estados Unidos en el nuevo orden mundial (Editorial Taurus, 2003$)$ I59.

37 J. Habermas, J. Derrida, El Derecho internacional en la transición bacia un escenario posnacional. Europa: en defensa de una política exterior común (2003, 2008) 9. 
the twenty-first century threat of long range missiles launched from countries such as Iran or North Korea". These agreements were made without any consultation with the EU or its Member States, and much less with their prior agreement, in spite of their direct impact on European defence, security and relations with Russia. The project was subsequently cancelled.

(ii) The expansion of the Atlantic Alliance, the United States and Russia. The Atlantic Alliance is the foundation stone of the collective defence of EU Member States and the US. The policy of expanding NATO, sponsored by the United States, would have a profound impact on global balances that Russia finds unacceptable ${ }^{38}$. The possibility of extending the Alliance to include Georgia or Ukraine stretched tensions to the maximum, as would subsequently also occur in the case of the EU association agreements. There is no advantage to be gained from increasing the strategic gap between Europe and Russia and EU Member States need to adopt a consistent position on international security, the expansion of NATO and security relations with Russia. Relations with Russia are characterised by Europe's defensive weakness and energy dependence, which restrict, as they do with regard to the United States, its room to manoeuvre.

\section{(E) ON THE EU'S DEFENCE OF THE APPLICATION OF INTERNATIONAL LAW AND ITS INTERNATIONAL PRACTICE WITH RUSSIA.}

Article 2I.I of the Lisbon Treaty states that the EU's action will be guided by a series of principles that include, amongst others, respect for the principles of the United Nations Charter and international law. The declaration of independence by Kosovo ${ }^{39}$, adopted on 17 February 2008 and supported by the majority of EU Member States, poses the question of whether the EU's reaction was in agreement with international law. The answer is clearly no.

The EU's practice in such matters dates from 1983, when it agreed not to collectively recognise the Turkish Republic of Northern Cyprus. The subsequent declarations adopted on 16 December 1991, one presenting guidelines on the recognition of new states in Eastern Europe and in the Soviet Union and the other on Yugoslavia established conditions for recognition linked to democracy and human rights. Did the Kosovo people, by virtue of international law, have the right to split from? Kosovo was not a colony, was not occupied and was not oppressed and the theory of it constituting a 'unique case', as claimed by the EU Council, does not hold. Kosovo, at the time of its Declaration of Independence and during the previous ten years, had been under international administration, so it is impossible to consider that its people were oppressed. UN Security Council Resolution I244 (1999) provided the framework for a multilateral solution that respected the territorial integrity of Serbia and was based on the consensus achieved between the Security Council's permanent members.

When drawing up his plan for Kosovo, the Finnish jurist Ahtisaari appeared to have forgotten the

${ }_{38}$ The Atlantic Alliance's current members are: Iceland, the United Kingdom, Denmark, the Netherlands, Belgium, Luxembourg, France, Portugal, Spain, Italy, Estonia, Latvia, Lithuania, Germany, Poland, the Czech Republic, Slovakia, Hungary, Slovenia, Rumania, Turkey, Bulgaria and Greece. The countries aspiring to membership are Georgia, Ukraine, Macedonia, Albania and Croatia.

39 On this issue, and prior to the Declaration itself, see R. Bermejo, C. Gutiérrez España, La independencia de Kosovo a la luz del Derecho de libre determinación (Documento de trabajo $\mathrm{n}^{\circ}$ 7/2008, Real Instituto Elcano). 
Aaland Islands question ${ }^{40}$, an example that deserves citing here. The Council of the League of Nations considered that the right of self-determination of peoples was not a generally recognised one, a positive rule of the Law of Nations. On the contrary, its opinion was that "international law does not recognize the right of national groups to separate themselves from the State of which they are a part by the simple expression of a wish, any more than it recognizes the right of other States to claim such a separation", concluding that "the grant or refusal of the right to a portion of its population of determining its own political fate by plebiscite or by some other method, is, exclusively, an attribute of the sovereignty of every State which is definitively constituted". It did, however, consider that "the separation of a minority from the State of which it forms a part and its incorporation into another State can only be considered as an altogether exceptional solution, a last resort when the State either lacks the will or the power to enact and apply just and effective guarantees; separation would be possible, as an exceptional measure, if the State oppresses a part of its population, in violation of the law, at which time the minority would be entitled to do the same"4r. The independence of Kosovo was determined by geopolitical considerations, not by legal reasons. Time will tell whether Kosovo succeeds in consolidation itself as a state by virtue of the principle of effectiveness, of great importance for the creation of states ${ }^{42}$.

There would be no difficulty in affirming that the creation of Kosovo took place in contravention of the principle forbidding the use of force, even though the territory was under international administration, due to the prior use of force by NATO in 1999 with neither UN consent nor in legitimate defence, merely invoking humanitarian reasons, which do not enjoy majority support in international law. Nor would it be difficult to affirm that the creation of Kosovo took place against Serbia's territorial sovereignty or other principles. Russia therefore declared it "null and void" in a statement issued by the Russian Foreign Ministry on 17 February 2008. The recognition of Kosovo by such a large number of EU Member States calls the compliance of their behaviour with the norms of international law into question.

Above all, however, it should not be forgotten that subsequent events in Ukraine, Crimea, South Ossetia and Abkhazia are not wholly unrelated to Western behaviour in Kosovo: one reaps what one sows. The reason invoked by Russia for its effective and immediate counter-offensive in support of South Ossetia and Abkhazia ${ }^{43}$ was the protection of the lives of the inhabitants of South Ossetia, who

40 See F. Visscher, "La questions des Iles d'Aaland", Révue de Droit international et de législation compare (I92I), 45 ; Colijn, La decisión de la Société des Nations concernant les Iles d'Aaland, Amsterdam (1923); Boursot, La question des Iles d'Aaland et le droit des peuples à disposer d'eux-mêmes. Ed. Dijon (1923).

${ }^{4} \quad$ See C. Fernández Liesa, C. Díaz Barrado, F. Mariño Menéndez, La protección internacional de las minorías, (Ed. Ministerio de Trabajo y Asuntos Sociales, Madrid) (200I), at I36.

${ }^{42}$ See C. Visscher, "Observations sur l'effectivité en droit internacional public", 2 LXII, Révue de droit international public, LXII (1958), at 60I; A. Miaja de la Muela, El principio de efectividad en Derecho internacional (Cuadernos de la Cátedra Dr. J. Brown Scout, Valladolid, Universidad de Valladolid, 1958,) at II4; J. Touscoz, Le principe d'effectivité dans l'ordre internacional (LGDJ, Paris, 1964) pp. 255 ff.; J. Salmon, "La construction juridique du fait en droit internacional", 32 Archives de philosopbie du droit -Le droit internacional, (1987) I35-15I.

43 South Ossetia broke off relations with Georgia in the I99I-92 war, and maintains close relations with North Ossetia. Its leader at the time, Eduard Kokoity, was in favour of independence: many South Ossetians are Russian passport holders, the majority of them Christians. In the case of Abkhazia I0,000 people lost their lives in the war with Georgia (1992-94) for its independence, and a further 250,000 were displaced, out of a total population of 340,000 , according to figures provided by 
were being subject to genocide. The EU mediated between Russia and Georgia to achieve a ceasefire and used diplomatic channels to monitor its effective compliance. After first negotiating with Georgia, President Sarkozy of France met with the Russian President in Moscow, entering with a 4-point peace plan and leaving with a 6-point plan to offer to Georgia. The commitments appearing in this final plan, which makes no reference to Georgia's territorial integrity, were the following:

I. The non-use of force

2. The definitive cessation of hostilities

3. Free access for humanitarian aid

4. The withdrawal of the Georgian military forces to their usual bases

5. The withdrawal of Russian military forces to the lines they held before hostilities broke out

6. The opening of international discussions on the modalities of security and stability in Abkhazia and South Ossetia.

The cessation of hostilities decreed by Russia was provisional on Georgia's acceptance of the Peace Plan, which was made effective by President Saakashvili on I4 August, after US Secretary of State Condoleezza Rice had persuaded him to put aside his initial misgivings. On 25 August the Russian Parliament voted unanimously in favour of recognising the regions of Abkhazia and South Ossetia as independent nations, and the following day President Medvedev signed the corresponding decrees of recognition. To justify their stance Russia alleged that Georgia had chosen genocide as a means of achieving its political ends, thereby scuppering any hope of peaceful coexistence between Ossetians, Abkhazians and Georgians in the same state. Furthermore, President Medvedev published an article in the Financial Times explaining his reasons for recognising the breakaway of these two Georgian regions, which mirrored those alleged at the time to justify the independence of Kosovo. He began by referring to the way in which minorities were treated, with specific reference to the stripping of the autonomy of the two regions in question by Georgia, which inflicted a "vicious war on its minority nations", a similar argument to that invoked in the case of Kosovo. He then went on to argue that the Georgian attack in early August had created a wholly new situation, saying that the precedent of Kosovo had been a decisive factor, since "in international relations, you cannot have one rule for some and another rule for others". Similar arguments have also served as the basis for the situation in Crimea and Ukraine and the justification given by Russia for its unlawful international acts.

All other considerations apart, the EU needs to hold to uniform interpretations when the same principles are invoked in different situations if it wishes to avoid being accused of acting purely in accordance with its own interests. Europe's straying from the correct interpretation of international law in Kosovo and Iraq allowed Russia to do the same in Crimea and Ukraine at a later junction. Lessons have to be learnt in order to avoid any future repetition of the same mistakes; consistency is of paramount importance if we want a world that functions in accordance with values and rights rather than imperial interests. It is to be hoped that these reflections will serve to highlight the risk of abandoning values as and when interests dictate, due to the effect of such a course of action on the

the then president Sergei Bagapash. The region's coasts account for almost half of Georgia's total coastline and almost half of its population (45\%) is of Georgian origin, the rest being Abkhazians (I8\%) and members of other ethnic groups, above all Russians and Armenians. $80 \%$ of its inhabitants are Russian passport holders. 
behaviour of other players and subjects that form part of the modern International Community.

\section{(F) ON RUSSIA AND THE PRINCIPLE OF NON INTERVENTION IN INTERNAL AFFAIRS}

More recently, it is obvious that Russia is trying to destabilise the western world. This is an answer to the western economic sanctions. In reality, Russia is not as strong as it would like the world to believed. We are forced to understand each other in a few years. From now to then Russia is engineering a division among the western world, in different scenario, such as United States of America, United Kingdom, Greece and Spain (in Catalonia affair).

In United States of America, Russian secret services helped Donald Trump candidature against Hilary Clinton, by propagating false accusations which helped Trump to get is way. Because of this some American authorities are investigating Trump Administration and candidature.

In the case of Great Britain, Russia supported Brexit just to divide European Union (divide et Impera; divide and rule), knowing that Britain is one of the largest countries that contributes economically and politically to the European Union. Furthermore, this also divide British nation; and finally the negotiations between the European Union ant the United Kingdom for Brexit will be a difficult ending.

Talking about Greece during its crisis, Russia stimulated the division; at a certain time Greece opposed to the sanctions given to Russia. This shows that Russia has been in contact with Greece, in a context of weakening of entire European Union.

Recently, experts from the European Union have said that Russia is helping in propagating false messages in favour of Catalan secessionist crisis. From the point of view of Public International Law Catalonia's steps of holding independence are inconsistent with International law. The population of Catalonia is not a people entitled with the right to self determination.

From this perspective, third States can violate the principle of non-intervention in international affairs. For example, Ecuador has told "wikileaks" founder Julian Assange, to avoid making statements that could affect the country's international relations after he expressed support for Catalonia independence. The Ecuadorian authorities - says the Press- have reiterated to Mr. Assange his obligation not to make statements or activities that could affect Ecuador's international relations, which must be preserved, as is the case with Spain. Responding on twitter, Assange accused Ecuadorian President Moreno of attempting to silence him. He wrote: "if President Moreno want to gag my reporting of human rights abuses in Spain he should say so explicitly, together with the legal basis". The Australian hacker, who has been sheltered at Ecuador Embassy in London last years, is believed to be wanted by USA for reveal state secrets.

Mr. Janis Sarts (Head of NATO strategic communication centre), declared 22 November 2017 that the ultimate goal of Russia is not to encourage Catalan independence, but rather to underscore divisions that will weaken the European Union and North Atlantic Treaty Organization itself. NATO intelligence Report shows that Russian online networks have been focusing their activities on Catalonia in order to make the most of the secessionist. The basic reason for those activities is to create confusion and aggravate western problems. According to NATO specialists there are various 
Russian actions in the interference process in Catalan crisis. The Catalan issue is internal and must be resolved with the Spanish constitutional order, declared NATO representative. The practice of disseminating and 'viralizing' contents about foreign crisis is aimed at creating the sense that everybody has problems, that the west is full of hypocrisy, and that all governments act in similar ways. Even though President Putin has claim that Catalan problem is an internal question, on the other hand it seems as if he is involved in a shadowy way.

In a final reflexion all the above shows that Putin want to destabilise western world. To that purpose some times Russia has violated the principle of non-intervention in international affairs, although it is difficult to prove. 